\title{
BIOTIC INDICES TO EVALUATE WATER QUALITY: BMWP
}

\section{JAIR J. PINEDA-PINEDA ${ }^{1}$, JOSE LUIS ROSAS-ACEVEDO ${ }^{1}$, JOSE MARIA SIGARRETA-ALMIRA ${ }^{2}$, JUAN CARLOS HERNANDEZ-GOMEZ ${ }^{2} \&$ MAXIMINO REYES-UMANA ${ }^{1}$}

${ }^{I}$ Regional Development Sciences Center, Autonomous University of Guerrero. Los Pinos s/n,

Suburb El Roble, Acapulco, Guerrero, Mexico

${ }^{2}$ Academic Unit of Mathematics-Acapulco, Autonomous University of Guerrero. Carlos E. Adame,

Suburb Garita, Acapulco, Guerrero, Mexico

\begin{abstract}
From a bibliographic analysis of the major published research studies about the index values used to evaluate water quality, the general characteristics of the so-called Biological Monitoring Working Party (BMWP) index are described; the degree of complexity of water quality assessments is measured and the integration of new technologies is analyzed through the use of Geographic Information Systems (GIS). The BMWP index is studied, as well as its applications from 1978 to 2017, specifying its temporal and spatial distribution, its current trends and complementary values. The analysis is based on the application of the Graph Theory, particularly on the Social Networks Analysis (SNA) from a holistic approach.

KEYWORDS: Bioindicator, Monitoring, Graphics, Network Analysis \& Holistic Approach
\end{abstract}

Received: Jun 21, 2018; Accepted: Jul 11, 2018; Published: Sep 19, 2018; Paper Id.: IJEEFUSOCT20184

\section{INTRODUCTION}

The quality of water resources is altered by anthropogenic activities, population growth, and natural phenomena, among other factors, which stress ecosystems and risk water availability. The approach to assess it has been developed on three fundamental pillars: physical, chemical and biological. For this purpose, the use of biological metrics stands out by being less expensive, less complex and depending on the bio indicator used they provide spatial and temporal information. (Barbour, Gerritsen, Snyder, \& Stribling, 1999; Kumar, Colton, Springer, \& Trama, 2013; Mangadze, Bere, \& Mwedzi, 2016; Soldner et al., 2004; Yazdian, Jaafarzadeh, \& Zahraie, 2014) Moreover the Biotic indices to assess water quality in freshwater ecosystems have been applied since last century (Armitage, Moss, Wright, \& Furse, 1983; Hilsenhoff, 1977; Kolkwitz \& Marsson, 1909; Woodiwiss, 1964) and its development with theoretical mathematical support (Margalef, 1951; Shannon \& Weaver, 1998; Simpson, 1949) became popular in the 50's.

The Biological Monitoring Working Party index (BMWP) takes into consideration the presence or absence of aquatic macro invertebrates to evaluate water quality. It was developed based on the sensitivity of these family groups to different degrees of organic pollution in rivers, without taking into account the abundance of each taxon (Hawkes, 1998). It grew to be used as a worldwide reference (Basset et al., 2012; Damanik-Ambarita et al., 2016; Forio et al., 2017; Muñoz-Riveaux et al., 2003; Pérez, 2003; Romero et al., 2017; Rosas-Acevedo et al., 2014), even though the original theory hadn't been published. 
In Spain, Alba-Tercedor and Sánchez-Ortega (1988) modify the tolerance values of each macro-invertebrate family, adapt the BMWP references to local conditions (BMWP') and define five types and colors associated with the index value, to describe water quality, and in order to develop biological maps. On the other hand, the BMWP-Cu index (Muñoz-Riveaux et al., 2003), is a direct consequence of the BMWP'. Both methodologies describe how to map water quality, but do not show any representation. Additionally, Pérez (2003) suggests that the methodological theory for regionalization of water quality should be tailored to each region. On the other hand, Forero, Longo, Ramírez, Jairo, and Chalar (2014) in Colombia, develop the Multi-Metric Ecological Quality Index (ICE $E_{\mathrm{RN}-\mathrm{MAE}}$ ), as a biological and physicchemical method for the evaluation of water quality. It exploits the physical and chemical parameters, environmental gradients, abundance, and macro-invertebrate genus identification. Furthermore, they compare it with the BMWP-Col index (Pérez, 2003) and prove that both indicators provide similar information on the variability of water quality.

Kohlmann, Russo, Itzep, and Solís (2010) employ a cooperative methodology to assess water quality: using the BMWP'-Cr reference in two rivers of rural Costa Rican communities. Moreover, they integrate the participation of the scholar community through a survey, before and after the study of water quality. They conclude that the participants changed their minds about how they perceived their water-related environmental problems. On the other hand, the impact of anthropogenic activities on water quality in Iran is studied through the use of Geographic Information Systems (GIS) and comparative analysis between physicochemical and biological indexes -one of them the BMWP- and show that the biological indexes provide a better approach to the health level of ecosystems. (Sharifinia, Mahmoudifard, Namin, Ramezanpour, \& Yap, 2016)

In this way, a complete water quality assessment is governed by the monitoring of three major components: hydrological, physicochemical and biological. The latter, should target the response of species or communities to changes in their environment, and determine what the factors and activities that interfere directly or indirectly on water quality. (Chapman \& Organization, 1996; Hellawell, 2012) Moreover observed that, over time, water quality studies using the BMWP index, have also been integrating: new technologies, the participation of social actors or anthropic activity, more complex relationships between physicochemical, biological and environmental variables, the index itself as an aid to other metrics and their adaptation in lentic ecosystems(Castellanos Romero et al., 2017).

This article attempts to give a holistic approach to water quality studies, based on the BMWP index methodology, through measuring the degree of complexity of water quality studies, the application of the index in different ecosystems, the incorporation of new technologies (GIS) and the use of other metrics in water quality assessments.

\section{MATERIALS AND METHODS}

The bibliographical sources consulted present aquatic macro invertebrates as bio-indicators for the study of water quality, besides the application and adaptation of the BMWP index in different parts of the world, from 1978 to 2017. Scopus and Web of Science were used to identify the most relevant studies in specialized journals, in both English and Spanish. The research began with the keywords "BMWP index" and "water quality", from which 177 and 119 bibliographic sources respectively were obtained, as well as 25 more results from 'Google Scholar'. In the next phase, databases were integrated to avoid duplicate sources, and 45 records were discarded, given that their results were not relevant to the study. Among the 165 remaining studies, a random sample of about $62 \%$ (98 articles) was chosen. 
Table 1, describes the set of variables that are used for each particular aim. The data matrix is shown in Appendix 1. The degree of complexity was measured with the number of parameters used in each article consulted and is described in Table 2. To determine if the number of parameters used over time increased or decreased, the Pearson correlation coefficient was calculated to explain the relationship between the year and the number of parameters (IBM SPSS Statistics ver. 20). Google Earth 7.3.0 was used for geo-referencing rivers, streams, reservoirs, lakes, and other water bodies, in order to describe the spatial and temporal distribution of the use and adaptations of the BMWP index; the graphic representation was made with ArcMap 10.3. On the other hand, <<cartography and GIS>> includes four variables that are described in detail in Table 3.

Table 1: Objectives Description and Their Relation with Each Variable Defined

\begin{tabular}{|l|l|l|}
\hline \multicolumn{1}{|c|}{ Objective } & \multicolumn{1}{|c|}{ Variable } & \multicolumn{1}{c|}{ Description } \\
\hline $\begin{array}{l}\text { Measure the number of parameters used in } \\
\text { water quality studies. }\end{array}$ & $\begin{array}{l}\text { Sources and parameters (see, } \\
\text { figure 2) }\end{array}$ & $\begin{array}{l}\text { Author and physical, chemical and } \\
\text { biological parameters }\end{array}$ \\
\hline $\begin{array}{l}\text { Explain the relationship between the year and } \\
\text { the increase in the number of parameters used }\end{array}$ & Year and parameters & $\begin{array}{l}\text { Source publishing year and } \\
\text { parameter numbers measured in } \\
\text { the bibliographic sources }\end{array}$ \\
\hline $\begin{array}{l}\text { Identify the BMWP adaptation / application } \\
\text { trends at an Ecosystem level }\end{array}$ & Source, ecosystem and year & $\begin{array}{l}\text { Author, lentic or lotic ecosystem } \\
\text { and source publishing year }\end{array}$ \\
\hline $\begin{array}{l}\text { Describe the spatial and temporal distribution } \\
\text { of the BMWP application / adaptation }\end{array}$ & Country and year & $\begin{array}{l}\text { Country and source publishing } \\
\text { year }\end{array}$ \\
\hline $\begin{array}{l}\text { Detail the cartography and GIS used in water } \\
\text { quality }\end{array}$ & $\begin{array}{l}\text { Source, year and, } \\
\text { <<Cartography \& GIS >> }\end{array}$ & $\begin{array}{l}\text { Author, source publishing year } \\
\text { and see Table 2 }\end{array}$ \\
\hline $\begin{array}{l}\text { Identify the indexes or metrics used in the } \\
\text { assessment of water }\end{array}$ & Several Indices & $\begin{array}{l}\text { Biological, chemical and } \\
\text { multimeter }\end{array}$ \\
\hline
\end{tabular}

Since it is possible to obtain quantitative data or significant statistics from the collection of the data described here, in this review we used the Social Network Analysis (ARS), which includes a set of qualitative measures to describe the structure and development of networks, which allowed describing the general relationships between the variables in Table 1, in addition, a graph was developed with Gephi 0.9.1 (Bastian, Heymann, \& Jacomy, 2009). The graph analyzed is not directed (simple), with nodes (vertices); associated with the author, ecosystem, country, year, parameters, <<cartography and GIS>> and indexes. The edges represent the relationships: Source/parameters, source/ecosystem, source/<<cartography and GIS>>, country, year and indexes (Wasserman \& Faust, 1994). In correlation, the modularity algorithm was applied (Blondel, Guillaume, Lambiotte, \& Lefebvre, 2008) to describe the similarity between communities.

\section{RESULTS AND DISCUSSIONS}

Figure 1, describes the variables behavior in a global way. The revised studies are arranged as central nodes (author or source), labeled with a number, sorted down from the highest node degree (the one with the most correlations). The index has been applied in lotic ecosystems. 2014 is the year with the most published sources. The indexes BMWP, ASPT, Shannon-Weaver, and Margalef are the most employed. On the other hand, $61.2 \%$ of the consulted research studies use cartography or satellite images for the study area description. In addition, the most used parameters were: Dissolved Oxygen, Temperature, $\mathrm{pH}$, Electrical Conductivity.

\section{ARE WATER QUALITY STUDIES COMPLEX?}

Among the 98 reviewed research studies, only 42 parameters were considered for the source-parameter correlation, but others such as latitude, altitude, slope, substrate, and riparian vegetation were not considered. However, it 
should be noted that some of these parameters are analyzed within the Cartography or GIS section. The 'parameter' variable showed values between 0 and 23 as minimum and maximum. The average value of measured parameters was $7.3 \pm 5.58$ per source consulted. The quartiles values were: 2.75 (First), 7.5 (Second) and 11 (Third).

On the $19 \%$ of the consulted sources did not report some parameter, since the selected sample did not discriminate between studies that diagnose water quality and methodologies that explain the adaptation of the index. It is wise to recognize there are methodologies that include case studies where the proposed index is validated. On the other hand, $4 \%$ of the reviewed sources measure more than 18 parameters, which indicate that water quality assessment is more rigorous in some countries. According to the quartiles, the results of water quality studies are classified and shown in Table 2.

Dissolved oxygen, $\mathrm{pH}$ and temperature are the most measured parameters, and the match the top three records sent to the Water Quality Monitoring Data Repository of EPA. gov (STORET), and they're used to determine the minimum set of parameters that must be measured, to consider a reliable study of water quality, while for particular or contextualized studies other parameters should be included. For example, total and fecal coliforms, arsenic, mercury, boron, and, nitric acid, among others.

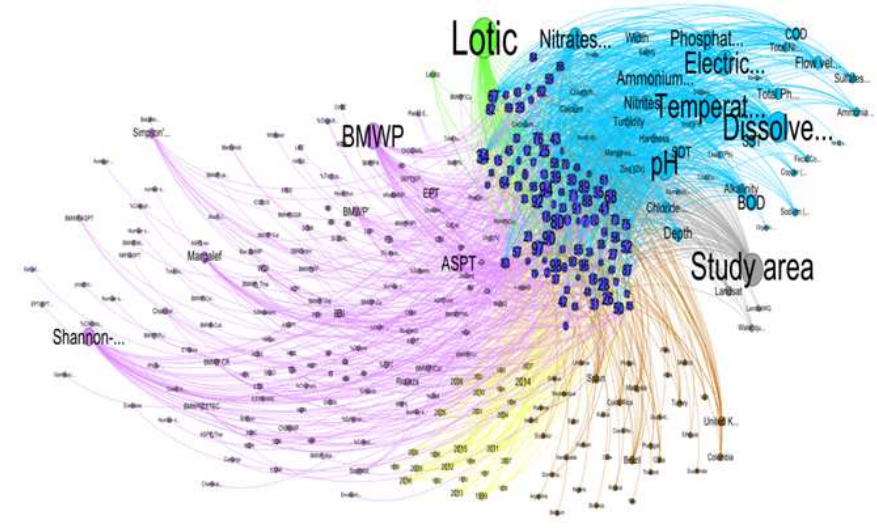

Figure 1: Graph of the Data Matrix, Where Variables Grouped By Colors

Table 2: Classification of Quality Studies According to the Measured Parameters

\begin{tabular}{|c|l|c|c|}
\hline Parameters & \multicolumn{1}{|c|}{ Study } & Frequency & Percent \\
\hline $0-3$ & Diagnostic & 27 & 27.6 \\
\hline $4-8$ & Basic & 31 & 31.6 \\
\hline $9-11$ & Half complex & 18 & 18.4 \\
\hline$>=12$ & Complex & 22 & 22.4 \\
\hline
\end{tabular}

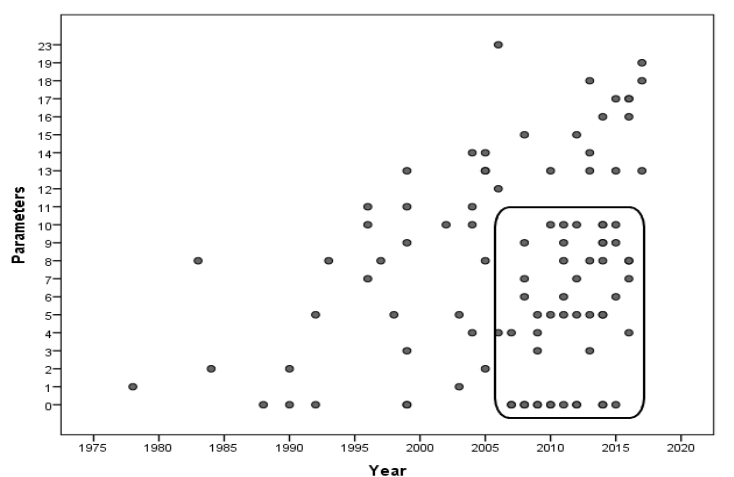

Figure 2: Scatter Diagram of the Year/Number of Parameters Correlation $(n=98$ y $p=0.05)$ 
To explain water quality study complexity in recent years, let us analyze the scatter diagram in Figure 2. It shows the correlation between the research publishing year and the number of parameters measured. The Pearson correlation coefficient was $\mathrm{R}^{2}=0.081$, proving that there is no positive linear correlation between the year of the source and the increase in the number of parameters measured. This indicates that the studies carried out to evaluate water quality are highly complex and, essentially, contextualized. Basically, it is because North America and the Western Asia countries are still developing basic methodologies related to the BMWP index. In Figure 2, the points enclosed within the rectangle belong to those water quality studies carried out in the last 11 years, which only applied the BMWP index or measure less than 11 parameters.

\section{SPATIAL DISTRIBUTION AND TRENDS}

Regarding the origin of the sources, the published research studies from Brazil, Colombia, Spain, and the United Kingdom constitute more than a third part of the consulted resources. The rest of the papers are distributed in 33 countries from around the world. Figure 3, shows the 37 Source/Country communities, in which the quantity and origin of the research articles reviewed are shown. The community size is determined by the number of nodes; the degree of the nodes represents the number of papers reviewed and the label shows the country of origin for the research.

For a more detailed analysis of the spatial and temporal distribution of the BMWP index application, the study was filtered by decade. From 1978 to 1990, the BMWP index was applied in the United Kingdom and Spain. Its use increases from 1991 to 2000, mainly in Europe, in countries like Portugal, Poland, Greece, and Slovakia. In addition, in the same period, its application reaches Latin American countries such as Argentina, Brazil, and Colombia. From to 2001 to 2010, it starts getting used in Africa (Egypt and Mozambique), Asia (Iran, Malaysia, and Thailand) and other countries in Latin America (Cuba, Costa Rica and Venezuela, among others). From 2001 to 2010, it began its application in Africa (Egypt and Mozambique), Asia (Iran, Malaysia, and Thailand) and other countries in Latin America (Cuba, Costa Rica, Venezuela and among others). From 2011 to 2017, Mexico, Russia and other countries in Asia (India and Vietnam) share its use. This period is the one with the most water quality studies reported (44). A general description is shown in Figure 4, elaborated with data obtained from the geo referencing of the reviewed papers.

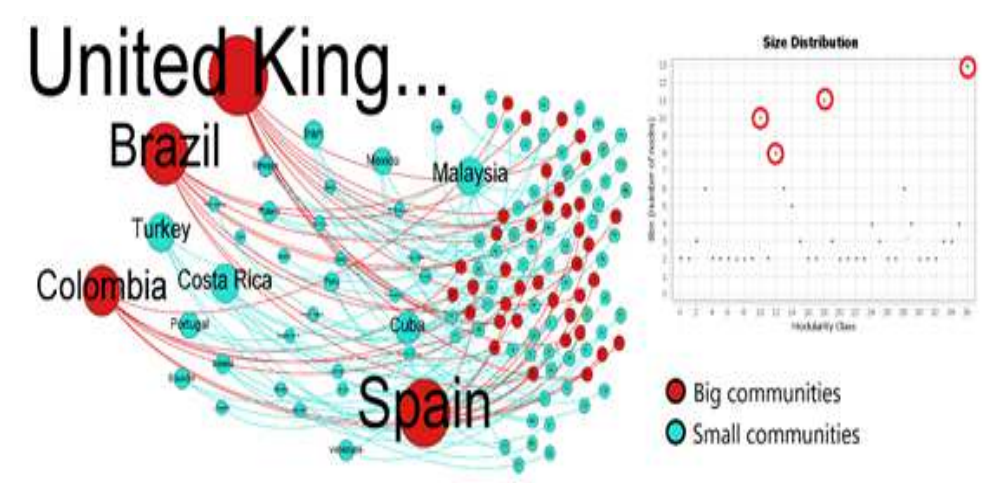

Figure 3: Community Distribution by Country/Source. The Graph on the Right Shows the Node Number in Each Community. The Red Circles Represent the Largest Communities

Note that in Europe there are a large number of water quality studies, which are based on the absence or presence of macro invertebrates and the BMWP index, or any of its variations, followed by America, Asia, and Africa. Since its initial theory, the BMWP index has been applied to lotic ecosystems, but since 2013 its application in lentic ecosystems has increased. 


\section{CARTOGRAPHY AND GEOGRAPHICAL INFORMATION SYSTEMS}

Among the 98 reviewed papers, only five research studies were conducted in lentic ecosystems areas, corresponding to countries such as Colombia, Ethiopia, Guatemala, India, and Mexico. This study shows that only three countries (Colombia, Mexico, and Ethiopia) study the water quality in both ecosystems. In this way, the popularity, adaptability and reliability of the BMWP index is manifested due to the fact that after 38 years since the developing the BMWP index, $44.89 \%$ of the studies have been carried out in the last six years, and that in the last four years it has been applied to other ecosystems.

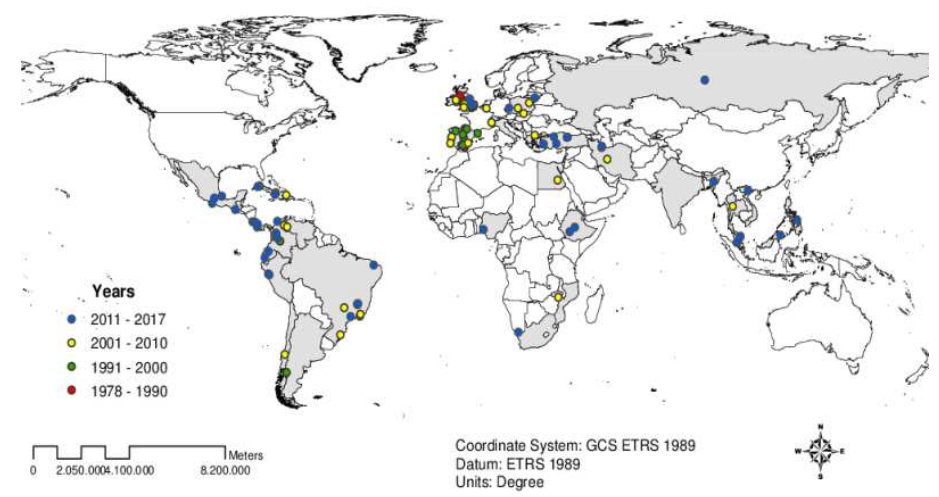

Figure 4: Spatial and Temporal Distribution of the BMWP Index Application or Adaptation (1978 - 2017).

Four variables were classified to evaluate the $<<$ Cartography and GIS $>>$. Their description and nomenclature are shown in Table 3.

Table 3: Variables that Describe the Cartography and GIS Use

\begin{tabular}{|l|l|}
\hline \multicolumn{1}{|c|}{ Variable } & \multicolumn{1}{c|}{ Description } \\
\hline Study area (SA) & Satellite image or map that only describes the study area. \\
\hline Water Quality (WQ) & $\begin{array}{l}\text { Cartography that uses intervals and water quality classes, according to } \\
\text { (Alba-Tercedor and Sánchez-Ortega (1988)). }\end{array}$ \\
\hline Landsat (LT) & Satellite image that describes the study area and other environmental gradients (GIS) \\
\hline LandsatWQ (LTWQ) & Satellite image used to relate environmental gradients with water quality (GIS). \\
\hline
\end{tabular}

Among the consulted sources two large groups can be spotted, among which 24 analyze the study area descriptively (zero degrees node) and 60 describe the study area with maps or satellite images. Eight use satellite images or maps to study the area and other environmental variables. The rest of them are defined in Figure 5: the red circle encloses the revised sources that use water quality cartography as described by Alba-Tercedor and Sánchez-Ortega (1988).

Of the sources analyzed, only $4.9 \%$ use water quality cartography, maps, and satellite images to describe the study area. And only two integrate the four variables described in Table 2 . The fact that only five of the 98 sources reviewed use regionalization by colors described since 1988 by Alba-Tercedor and Sánchez-Ortega (1988) and later by Pérez (2003) and Muñoz-Riveaux et al. (2003); shows the absence of an explicit methodology for the elaboration of water quality maps associated with BMWP index. Although in more recent Works (Romero et al., 2017) the use of GIS for the regionalization of water quality is observed, without describing the methodology used for the elaboration of maps of water quality, necessary in the spatial and temporal description of the conditions of the body of water. 


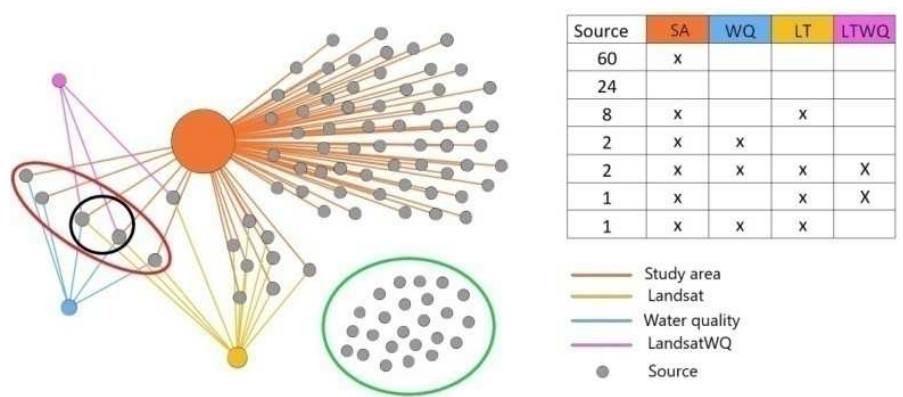

Figure 5: General Correlation Cartography/Sources

Parameters such as latitude, altitude, slope, depth, chlorophyll, substrate, riparian vegetation, temperature, total suspended solids and nitrates can be calculated through satellite images, by the use of multispectral sensors (Bierman, Lewis, Ostendorf, \& Tanner, 2011; Gómez Díaz \& Dalence Martinic, 2014; Norat Ramírez, Mattei, Barreto, \& Luhring González, 2002; Rivera Vázquez, Vargas Pérez, Terrazas Domínguez, \& Gavi Reyes, 2002; Trangmar, Yost, \& Uehara, 1986). For example, depth is related to bathymetry, riparian vegetation is related to vegetation or type of land use. Furthermore, nowadays there are digital elevation models that include: latitude, altitude, and slope.

\section{OTHER METRICS OR INDEXES}

The 277 nodes shown in Figure 6 are distributed in 142 indexes (physical, chemical, biological and other metrics), 98 revised research study papers and 37 countries around the world. The degree of the nodes associated with BMWP, BMWP', ASPT, Shannon-Weaver, Margalef, EPT, WQI and Simpson indexes are the most cardinal in the graph studied, which shows that they are the most widely used. This implies the transition from the qualitative to a quantitative sampling type to describe the ecosystems health state. Besides, the application of the WQI index reflects on the presence of physicochemical parameters.

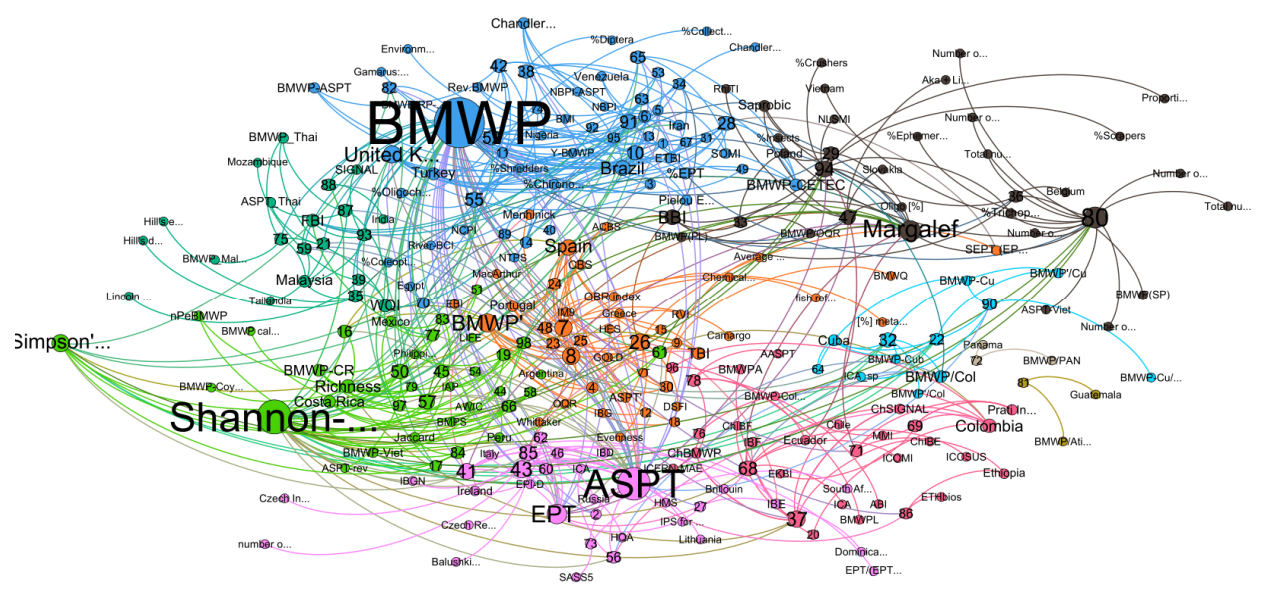

Figure 6: Communities Composed of Nodes: Indexes, Sources, and Countries, With a Modularity of 0.515

The 10 communities (modularity class) described in Appendix 2, reveals the similarities among the index application in different countries, and their size is determined by the number of nodes that confirms it. Countries like Egypt, Nigeria, Venezuela, Iran, Turkey, Brazil, and the United Kingdom, are part of the larger community (61 nodes), whilst Cuba, Panamá and Guatemala are in the smallest, highlighting that Cuba uses more indexes than Panama and Guatemala for their water quality studies. 
From the analysis of papers consulted, associated with evidence, the importance of the contextualization of water quality studies is demonstrated. Therefore, it is necessary to add new taxa or to adapt the tolerance values of the macroinvertebrate families of each region and ecosystem, for the BMWP index methodology application. This reinforces the idea of the BMWP adaptability and validation. A sample of the foregoing appears in the bibliography as Y-BMWP, BMWPTHAI, BMWP-Viet, BMWP/Atitlán, BMWP'/PAN, BMWP-CETEC, BMWP (PL) y BMWP-Coyuca.

On the other hand, index application (node degree less than 3) is relative to the complexity of the particular studies and the type of correlation to be analyzed. Moreover, the increase in emerging pollutants makes it necessary to resort to other metrics in order to have a better perspective the health of the ecosystems. The large variety of indexes or metrics used in the evaluation of water quality means that there is no index that could be adopted in general, or that could work correctly in different ecosystems.

It is known that water quality studies that use bio indicators, as a rule, are governed by variables such as study area, physical-chemical parameters, biotic indexes and correlations with other metrics. According to that, water quality studies can be described in relation to the variables observed, such as Parameters: physical, chemical, microbiological and environmental. They allow the description of particular elements and conditions. Indexes: biological, physicochemical and multimetric. They describe the ecosystem dynamics qualitatively and quantitatively and use one or several parameters for its calculation. GIS help describes the environment of water bodies to integrate other environmental variables, in addition to spatial and temporal analysis.

On the other hand, some of the analyzed sources integrate aspects such as Anthropogenic activities, the activities that surround the water body or for which the water resource is used (Blijswijk, Coimbra, \& Graça, 2004; Duran, 2006; Garcia-Criado, Tomé, Vega, \& Antolin, 1999; Gray \& Delaney, 2008; Guevara Mora, 2011; Holguin-Gonzalez, Everaert, Boets, Galvis, \& Goethals, 2013; Mesgaran Karimi, Azari Takami, Khara, \& Abbaspour, 2016; Stein, Springer, \& Kohlmann, 2008; Yoshida \& Rolla, 2012). The inclusion of public and educational institutions (Rico, Rallo, Sevillano, \& Arretxe, 1992). Study of invasive species (Arbačiauskas, Višinskienė, \& Smilgevičienė, 2011; MacNeil \& Briffa, 2009) or with the presence or absence of other ones (Bedford, 2009). Ecological evaluations (Šporka, Pastuchová, Hamerlík, Dobiašová, \& Beracko, 2009), correlations with changes in the landscape (Yoshida \& Rolla, 2012) and land use (Munyika, Kongo, \& Kimwaga, 2014).

The General Systems Theory (Von Bertalanffy, 1969) raises that the phenomena must be studied as a whole, that is, all the parts, the associated processes, the organization and the order that links them. This theory proposes the wellknow holistic approach for the study of systems, taking into account the elements that intervene and correlations established between them. Hence, the ecosystem seen as a system allows interrelating the variables and aspects described in this review, to give a holistic approach to water quality studies. Figure 7 describes the general correlations in water quality assessment which apply the BMWP index (according to the grayscale, they go from basic to complex, also considering the increase in the number of variables studied).

\section{CONCLUSIONS}

The aim and scope of the research works that assess water quality through aquatic macro-invertebrates, which apply or adapt the BMWP index are heterogeneous and multidimensional. The parameters mostly used for this analysis (dissolved oxygen, $\mathrm{pH}$ and temperature) are in order of importance, depending on the direct impact on the communities or 
species and the information that it's contributes of the health of the ecosystem of immediate way. There is no correlation between the increase of the parameters studied and the year of study. The spatial and temporal distribution of the studies carried out in different countries that apply or adapt the BMWP index, from the theory to the initial application, let us certify that the United Kingdom, Spain, Brazil, and Colombia are the nations that contribute most of the scientific work in the field of water quality evaluation. In addition, this distribution shows a clear tendency of typical taxonomic groups to adapt to lentic ecosystems in recent dates.

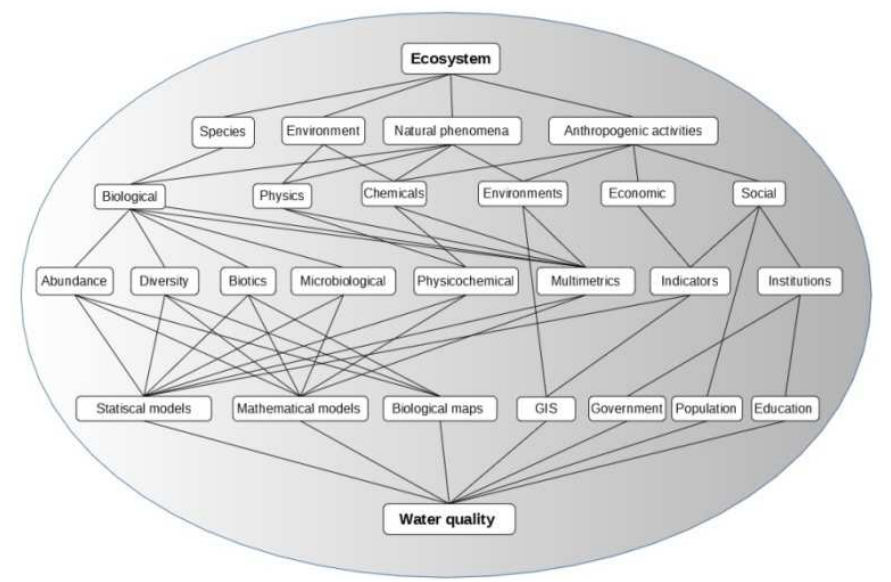

Figure 7: Water Quality Studies Viewed as a System

There is not the methodology that describes in a general way the making of maps associated with water quality studies that use the types and BMWP index value as reference elements. It is evident that there is a tendency to use technology in these studies. For example, some parameters that used to be measured with traditional methods before, have been proven to be described through the use of satellite images or sensors nowadays. Among the 142 identified indexes, the most used in the specialized literature are the following: BMWP, ASPT, BMWP', Shannon-Weaver, Margalef, and Simpson. This corroborates that the most used sampling methods in the present for water quality assessment are varied and non-directional, that means they are both qualitative (BMWP, ASPT, BMWP') and, quantitative (Shannon-Weaver, Margalef, and Simpson) and the taxonomic identification at different levels (family, gender or species) is used in both of them.

\section{ACKNOWLEDGEMENTS}

We acknowledge the Council for Science and Technology Mexico (CONACYT), for the support provided through a postgraduate scholarship to the first author.

\section{REFERENCES}

1. Alba-Tercedor, J., \& Sánchez-Ortega, A. (1988). Un método rápido y simple para evaluar la calidad biológica de las aguas corrientes basado en el de Hellawell (1978). Limnetica, 4(5), 1-56.

2. Arbačiauskas, K., Višinskienè, G., \& Smilgevičienè, S. (2011). Non-indigenous macroinvertebrate species in Lithuanian fresh waters, Part 2: Macroinvertebrate assemblage deviation from naturalness in lotic systems and the consequent potential impacts on ecological quality assessment. Knowledge and Management of Aquatic Ecosystems(402), 13. doi: $10.1051 / \mathrm{kmae} / 2011076$ 
3. Armitage, P., Moss, D., Wright, J., \& Furse, M. (1983). The performance of a new biological water quality score system based on macroinvertebrates over a wide range of unpolluted running-water sites. Water research, 17(3), 333-347. doi: 10.1016/0043-1354(83)90188-4

4. Barbour, M. T., Gerritsen, J., Snyder, B. D., \& Stribling, J. B. (1999). Rapid bioassessment protocols for use in streams and wadeable rivers: periphyton, benthic macroinvertebrates and fish: US Environmental Protection Agency, Office of Water Washington, $D C$.

5. Basset, A., Barbone, E., Borja, A., Brucet, S., Pinna, M., Quintana, X., . . Simboura, N. (2012). A benthic macroinvertebrate size spectra index for implementing the Water Framework Directive in coastal lagoons in Mediterranean and Black Sea ecoregions. Ecological Indicators, 12(1), 72-83. doi: 10.1016/j.ecolind.2011.06.012

6. Bastian, M., Heymann, S., \& Jacomy, M. (2009). Gephi: an open source software for exploring and manipulating networks. Icwsm, 8, 361-362.

7. Bedford, S. J. (2009). The effects of riparian habitat quality and biological water quality on the European Otter (Lutra lutra) in Devon. Bioscience Horizons, 2(2), 125-133. doi: 10.1093/biohorizons/hzp015

8. Bierman, P., Lewis, M., Ostendorf, B., \& Tanner, J. (2011). A review of methods for analysing spatial and temporal patterns in coastal water quality. Ecological Indicators, 11(1), 103-114. doi: 10.1016/j.ecolind.2009.11.001

9. Blijswijk, W., Coimbra, C., \& Graça, M. A. (2004). The use of biological methods based on macroinvertebrates to an Iberian stream (Central Portugal) receiving a paper mill effluent. Limnetica, 23(3-4), 307-314.

10. Blondel, V. D., Guillaume, J.-L., Lambiotte, R., \& Lefebvre, E. (2008). Fast unfolding of communities in large networks. Journal of statistical mechanics: theory and experiment, 2008(10), P10008. doi: 10.1088/1742-5468/2008/10/P10008

11. Castellanos Romero, K., Pizarro Del Río, J., Cuentas Villarreal, K., Costa Anillo, J. C., Pino Zarate, Z., Gutierrez, L. C., .. . Arboleda Valencia, J. W. (2017). Lentic water quality characterization using macroinvertebrates as bioindicators: An adapted BMWP index. Ecological Indicators, 72, 53-66. doi: https://doi.org/10.1016/j.ecolind.2016.07.023

12. Chapman, D. V., \& Organization, W. H. (1996). Water quality assessments: a guide to the use of biota, sediments and water in environmental monitoring.

13. Damanik-Ambarita, M. N., Lock, K., Boets, P., Everaert, G., Nguyen, T. H. T., Forio, M. A. E., . . Landuyt, D. (2016). Ecological water quality analysis of the Guayas river basin (Ecuador) based on macroinvertebrates indices. LimnologicaEcology and Management of Inland Waters, 57, 27-59. doi: 10.1016/j.limno.2016.01.001

14. Duran, M. (2006). Monitoring Water Quality Using Benthic Macroinvertebrates and Physicochemical Parameters of Behzat Stream in Turkey. Polish Journal of Environmental Studies, 15(5).

15. Forero, L. C., Longo, M., Ramírez, R., Jairo, J., \& Chalar, G. (2014). Índice de calidad ecológica con base en macroinvertebrados acuáticos para la cuenca del río Negro (ICE RN-MAE), Colombia. Revista de Biología Tropical, 62, 233247.

16. Forio, M. A. E., Lock, K., Radam, E. D., Bande, M., Asio, V., \& Goethals, P. L. (2017). Assessment and analysis of ecological quality, macroinvertebrate communities and diversity in rivers of a multifunctional tropical island. Ecological Indicators, 77, 228-238. doi: 10.1016/j.ecolind.2017.02.013

17. Garcia-Criado, F., Tomé, A., Vega, F., \& Antolin, C. (1999). Performance of some diversity and biotic indices in rivers affected by coal mining in northwestern Spain. Hydrobiologia, 394, 209-217. doi:10.1023/A:100363422 
18. Gómez Díaz, J. L., \& Dalence Martinic, J. S. (2014). Determinación del parámetro sólidos suspendidos totales (SST) mediante imágenes de sensores ópticos en un tramo de la cuenca media del río Bogotá (Colombia). UD y la GEOMÁTICA(9). doi: 10.14483/issn.2344-8407

19. Gray, N., \& Delaney, E. (2008). Comparison of benthic macroinvertebrate indices for the assessment of the impact of acid mine drainage on an Irish river below an abandoned $\mathrm{Cu}-\mathrm{S}$ mine. Environmental Pollution, 155(1), 31-40. doi: 10.1016/j.envpol.2007.11.002

20. Guevara Mora, M. (2011). Insectos acuáticos y calidad del agua en la cuenca y embalse del río Peñas Blancas, Costa Rica. Revista de Biología Tropical, 59(2), 635-654.

21. Hawkes, H. A. (1998). Origin and development of the biological monitoring working party score system. Water research, 32(3), 964-968. doi:10.1016/S0043-1354(97)00275-3

22. Hellawell, J. M. (2012). Biological indicators of freshwater pollution and environmental management: Springer Science \& Business Media.

23. Hilsenhoff, W. L. (1977). Use of arthropods to evaluate water quality of streams. Wis. Dep. Nat. Resour. Tech. Bull., (100), 115. https://ci.nii.ac.jp/naid/10009315055/en/

24. Holguin-Gonzalez, J. E., Everaert, G., Boets, P., Galvis, A., \& Goethals, P. L. (2013). Development and application of an integrated ecological modelling framework to analyze the impact of wastewater discharges on the ecological water quality of rivers. Environmental modelling \& software, 48, 27-36. doi: 10.1016/j.envsoft.2013.06.004

25. Kohlmann, B., Russo, R., Itzep, J., \& Solís, R. (2010). Children's Participation in the Evaluation of Bio-Indicators of Water Quality in Rural Communities. Paper presented at the 21st Century Watershed Technology: Improving Water Quality and Environment Conference Proceedings, 21-24 February 2010, Universidad EARTH, Costa Rica.

26. Kolkwitz, R., \& Marsson, M. (1909). Ökologie der tierischen Saprobien. Beiträge zur Lehre von der biologischen Gewässerbeurteilung. International review of Hydrobiology, 2(1-2), 126-152. doi:10.1002/iroh.19090020108

27. Kumar, A., Colton, M. B. M., Springer, M., \& Trama, F. A. (2013). Macroinvertebrate communities as bioindicators of water quality in conventional and organic irrigated rice fields in Guanacaste, Costa Rica. Ecological Indicators, 29, 68-78. doi: 10.1016/j.ecolind.2012.12.013

28. MacNeil, C., \& Briffa, M. (2009). Replacement of a native freshwater macroinvertebrate species by an invader: implications for biological water quality monitoring. Hydrobiologia, 635(1), 321. doi: 10.1007/s10750-009-9924-4

29. Mangadze, T., Bere, T., \& Mwedzi, T. (2016). Choice of biota in stream assessment and monitoring programs in tropical streams: A comparison of diatoms, macroinvertebrates and fish. Ecological Indicators, 63, 128-143. doi: 10.1016/j.ecolind.2015.11.029

30. Margalef, $R$. (1951). Diversidad de especies en las comunidades naturales.

31. Mesgaran Karimi, J., Azari Takami, G., Khara, H., \& Abbaspour, R. (2016). Influence of trout farm effluents on water quality parameters and benthic macroinvertebrates. Iranian Journal of Fisheries Sciences, 15(1), 133-143.

32. Munyika, S., Kongo, V., \& Kimwaga, R. (2014). River health assessment using macroinvertebrates and water quality parameters: A case of the Orange River in Namibia. Physics and Chemistry of the Earth, Parts A/B/C, 76, 140-148. doi: 10.1016/j.pce.2015.01.001 
33. Muñoz-Riveaux, S., Naranjo-López, C., Garcés-González, G., González Lazo, D., Musle-Cordero, Y., \& Rodríguez-Montoya, L. (2003). Evaluación de la calidad del agua utilizando los macroinvertebrados bentónicos como bioindicadores. Revista Chapingo. Serie ciencias forestales y del ambiente, 9(2).

34. Norat Ramírez, J. A., Mattei, H., Barreto, M., \& Luhring González, N. I. (2002). Uso de terrenos y calidad del agua en la cuenca hidrográfica del Río la Plata en Puerto Rico. Congreso Interamericano de Ingeniería Sanitaria y Ambiental, 28, 1-8.

35. Pérez, G. R. (2003). Bioindicación de la calidad del agua en colombia: Propuesta para el uso del método BMWP Col: Universidad de Antioquia.

36. Rico, E., Rallo, A., Sevillano, M., \& Arretxe, M. (Eds.). (1992). Comparison of several biological indices based on river macroinvertebrate benthic community for assessment of running water quality (Vol. 28): EDP Sciences.

37. Rivera Vázquez, R., Vargas Pérez, E., Terrazas Domínguez, S., \& Gavi Reyes, F. (2002). Utilización de imágenes de satélite para determinar áreas con problemas de lixiviación de nitratos. Revista Chapingo. Serie ciencias forestales y del ambiente, 8(1). http://artificialwww.redalyc.org/articulo.oa?id=62980103

38. Romero, K. C., Del Río, J. P., Villarreal, K. C., Anillo, J. C. C., Zarate, Z. P., Gutierrez, L. C., . . Valencia, J. W. A. (2017). Lentic water quality characterization using macroinvertebrates as bioindicators: An adapted BMWP index. Ecological Indicators, 72, 53-66. doi: 10.1016/j.ecolind.2016.07.023

39. Rosas-Acevedo, J. L., Ávila-Pérez, H., Sánchez-Infante, A., Rosas-Acevedo, A. Y., García-Ibañez, S., Sampedro-Rosas, L., . . Juárez-López, A. L. (2014). Índice BMWP, FBI y EPT para determinar la calidad del agua en la laguna de Coyuca de Benítez, Guerrero, México. Revista Iberoamericana de Ciencias, 1(2), 82-88.

40. Shannon, C. E., \& Weaver, W. (1998). The mathematical theory of communication: University of Illinois press.

41. Sharifinia, M., Mahmoudifard, A., Namin, J. I., Ramezanpour, Z., \& Yap, C. K. (2016). Pollution evaluation in the Shahrood River: Do physico-chemical and macroinvertebrate-based indices indicate same responses to anthropogenic activities? Chemosphere, 159, 584-594. doi: 10.1016/j.chemosphere.2016.06.064

42. Simpson, E. H. (1949). Measurement of diversity. Nature. doi:10.1038/163688a0

43. Soldner, M., Stephen, I., Ramos, L., Angus, R., Wells, N. C., Grosso, A., \& Crane, M. (2004). Relationship between macroinvertebrate fauna and environmental variables in small streams of the Dominican Republic. Water research, 38(4), 863-874. doi: 10.1016/S0043-1354(03)00406-8

44. Šporka, F., Pastuchová, Z., Hamerlík, L., Dobiašová, M., \& Beracko, P. (2009). Assessment of running waters (Slovakia) using benthic macroinvertebrates-derivation of ecological quality classes with respect to altitudinal gradients. Biologia, 64(6), 1196-1205. doi: 10.2478/s11756-009-0201-9

45. Stein, H., Springer, M., \& Kohlmann, B. (2008). Comparison of two sampling methods for biomonitoring using aquatic macroinvertebrates in the Dos Novillos River, Costa Rica. ecological engineering, 34(4), 267-275. doi: 10.1016/j.ecoleng.2007.06.010

46. Trangmar, B. B., Yost, R. S., \& Uehara, G. (1986). Application of geostatistics to spatial studies of soil properties. Advances in agronomy, 38, 45-94. doi:10.1016/S0065-2113(08)60673-2

47. Von Bertalanffy, L. (1969). General system theory: foundations, development, applications (Revised Edition).

48. Wasserman, S., \& Faust, K. (1994). Social network analysis: Methods and applications (Vol. 8): Cambridge university press.

49. Woodiwiss, F. (1964). The biological system of stream classification used by the Trent-River-Board. Chemistry \& Industry(11), 443-447. 
50. Yazdian, H., Jaafarzadeh, N., \& Zahraie, B. (2014). Relationship between benthic macroinvertebrate bio-indices and physicochemical parameters of water: a tool for water resources managers. Journal of Environmental Health Science and Engineering, 12(1), 30. doi: 10.1186/2052-336X-12-30

51. Yoshida, C. E., \& Rolla, A. P. P. R. (2012). Ecological attributes of the benthic community and indices of water quality in urban, rural and preserved environments. Acta Limnologica Brasiliensia, 24(3), 235-243. doi: 10.1590/S2179975X2012005000041

52. Yusuf, Y. O., \& Ariko, J. D. Effect Of Dumpsites On Ground Water Quality In Zaria Metropolis, Kaduna State, Nigeria.. 
